\title{
Risk of cancer with metal-on-metal hip replacements: population based study
}

\author{
() (1) $\Theta$ OPEN ACCESS
}

\author{
Keijo T Mäkelä orthopaedic surgeon ${ }^{1}$, Tuomo Visuri associate professor ${ }^{2}$, Pekka Pulkkinen \\ statistician $^{2}$, Antti Eskelinen head of research unit ${ }^{3}$, Ville Remes associate professor ${ }^{4}$, Petri Virolainen \\ associate professor ${ }^{1}$, Mika Junnila orthopaedic surgeon ${ }^{1}$, Eero Pukkala professor ${ }^{56}$
}

${ }^{1}$ Department of Orthopaedics and Traumatology, Surgical Hospital, Turku University Hospital, FI-20701, Turku, Finland; ${ }^{2} \mathrm{Hjelt}$ Institute, Helsinki University, FI-00014 Helsinki, Finland; ${ }^{3}$ Coxa Hospital for Joint Replacement, FI-33101 Tampere, Finland; ${ }^{4}$ Department of Orthopaedics and Traumatology, Peijas Hospital, Helsinki University Central Hospital, FI-00029 Helsinki; ${ }^{5}$ School of Health Sciences, University of Tampere, FI-33100 Tampere; ${ }^{6}$ Finnish Cancer Registry, Institute for Statistical and Epidemiological Cancer Research, FI-00130 Helsinki

\begin{abstract}
Objective To assess the risk of cancer associated with modern primary metal-on-metal hip replacements.

Design Population based study.

Setting Nationwide retrospective comparative register.

Participants 10728 patients who underwent metal-on-metal total hip arthroplasty and 18235 patients who underwent conventional metal-on-polyethylene, ceramic-on-polyethylene, and ceramic-on-ceramic total hip arthroplasty (the non-metal-on-metal cohort) in the Finnish Arthroplasty Register 2001-10. Data on cancer cases up to 2010 for these cohorts were extracted from the Finnish Cancer Registry.

Main outcome measures The relative risk of cancer was expressed as the ratio of observed to expected number of cases from the Finnish population - that is, the standardised incidence ratio. The relative risk of cancer in the metal-on-metal cohort compared with the non-metal-on-metal cohort was estimated with analyses of these ratios and Poisson regression.

Results The overall risk of cancer in patients with metal-on-metal hip implants was similar to that in the Finnish population (378 observed $v$ 400 expected, standardised incidence ratio $0.95,95 \%$ confidence interval 0.85 to 1.04). The overall risk of cancer in patients with metal-on-metal hip implants was also no higher than in patients who had received non-metal-on-metal hip implants (relative risk 0.92, 0.81 to 1.05).
\end{abstract}

Conclusions Metal-on-metal hip replacements are not associated with an increased overall risk of cancer during a mean follow-up of four years.

\section{Introduction}

Metal-on-metal hip resurfacing arthroplasty and large diameter head total hip arthroplasty have regained popularity during the past 10 years. ${ }^{1-4}$ In Australia, over 30000 metal-on-metal hip replacements were carried out between 1999 and 2010 (population 21.5 million). ${ }^{5}$ Similarly, about 60000 such operations have been carried out in England and Wales since 2003 (population 54.4 million). ${ }^{6}$ In the United States, the figure is closer to a million (population 308 million). ${ }^{7}$

Recently, more complications involving wear of the metal-on-metal bearing surface have been detected. ${ }^{8-11}$ Metal debris can be dispersed throughout the body and has been found in the liver and spleen and in local and distant lymph nodes. ${ }^{12} 13$ Patients with metal-on-polyethylene bearings are also permanently exposed to chromium (Cr), cobalt (Co), and titanium (Ti). Metal debris from hip implants can be associated with chromosomal aberrations and DNA damage. ${ }^{14-16}$ There has been no reported increase in the risk of cancer after total hip arthroplasty with conventional metal-on-polyethylene or first generation metal-on-metal implants. ${ }^{17}{ }^{18}$ First generation metal-on-metal total hip arthroplasty included implants such as McKee-Farrar. They were implanted mostly during 1960s and 1970s. Extensive wear of some modern metal-on-metal designs ${ }^{19}$ has questioned the safety compared with the first generation designs. Studies have shown short term increased serum concentrations of chromium and cobalt in patients with metal-on-metal hips. ${ }^{20}$

Metal-on-metal implants have been widely used in Finland. The total number of hip resurfacings implanted in Finland (population 5.4 million) is more than twice the number in three other Nordic countries altogether (Sweden, Norway, Denmark, total population 18 million). ${ }^{21} \mathrm{We}$ assessed the risk of cancer associated with primary metal-on-metal hip resurfacing 
arthroplasty and large diameter head metal-on-metal total hip arthroplasty in patients who underwent the procedure in 2001-10 by combining data from the Finnish Arthroplasty Register and the Finnish Cancer Registry.

\section{Methods}

In this nationwide retrospective comparative register study patients were not directly contacted. We included only patients with primary or secondary osteoarthritis as a diagnosis and excluded patients with rheumatoid arthritis at baseline because they have a non-typical pattern of cancer. ${ }^{22} 23$

The metal-on-metal cohort included all patients who had received metal-on-metal hip resurfacings and large diameter head metal-on-metal total hip designs that had been used at least 20 times from 2001 to 2010. Patients who underwent metal-on-polyethylene, ceramic-on-polyethylene, or ceramic-on ceramic total hip arthroplasty during the study period were the reference cohort (non-metal-on-metal cohort) so we could determine how much of the increased or decreased risk of cancer is because of patient selection and how much might be related to the type of the implant. The metal-on-metal cohort comprised 10728 patients and the non-metal-on-metal cohort comprised 18235 patients (see supplementary tables A and B in the appendix). The femoral component of all hip resurfacings was always cemented. The acetabulum component of all hip resurfacings was always uncemented. All large diameter head metal-on-metal total hips were uncemented. There were 12051 cemented (66\%) and $6184(34 \%)$ uncemented total hips in the non-metal-on-metal cohort. The names and materials of the implants included are shown in supplementary table B in the appendix).

\section{Follow-up and statistical analysis}

Since 1980, the Finnish Arthroplasty Register has been collecting information on total hip replacements. ${ }^{24}$ Healthcare authorities, institutions, and orthopaedic units are obliged to provide the National Institute for Health and Welfare with information essential for maintenance of the register. Since 1995, the data in the register have been compared with data on hospital discharge registers every few years. Currently, $98 \%$ of implants are recorded in the Finnish Arthroplasty Register (M Peltola, personal communication, 2012).

We linked data from the Finnish Arthroplasty Register with data from the Finnish Cancer Registry using the personal identity codes given to every resident of Finland since 1967. Dates of death or emigration were obtained from the Population Register Centre. The patients were followed up for cancer incidence from the date of the first operation until death or until 31 December 2010. There were no losses to follow-up. Follow-up did not stop at the date of first diagnosis of cancer, and so all primary cancers diagnosed during the follow-up were counted as observed cases and included in the reference incidence rates.

The number of observed cases for each cancer and person years at follow-up were stratified by sex, calendar period, and five year age group and follow-up time since the operation. The calendar periods used were 2001-05 and 2006-10 and the follow-up categories were less than two years or two years and more since the operation. The expected number of each type of cancer was calculated by applying the number of person years in each stratum to the corresponding incidence rate for cancer in the Finnish population. The relative risk of cancer was expressed as the ratio of observed to expected number of cases - that is, the standardised incidence ratio. We used the risk ratio of the two standardised incidence ratios (SIR/SIR-ratio) to compare the metal-on-metal and the non-metal-on-metal cohorts. For the $95 \%$ confidence intervals, we assumed that the number of observed cases followed a Poisson distribution.

We also carried out a Poisson regression analysis to compare the cancer risk in the metal-on-metal and non-metal-on-metal cohorts for all cancers, soft tissue sarcomas, and basal cell carcinoma. We chose soft tissue sarcomas and basal cell carcinoma for Poisson regression according to the results in the analyses of standardised incidence ratios. Besides soft tissue sarcomas and basal cell carcinoma, we examined 12 other cancer types in analyses of standardised incidence ratios and found non-significant results. In Poisson regression analyses of all cancers, soft tissue sarcoma, and basal cell carcinoma, we stratified age in 10 year categories and follow-up time in three categories $(<2,2-5$, and $\geq 5$ years since the operation). We also added sex into the model.

\section{Results}

The metal-on-metal cohort included 38577 person years (table $1 \Downarrow)$. The proportion of men was $59 \%$. The mean follow-up was 3.6 years in the metal-on-metal cohort and 5.1 years in the non-metal-on-metal cohort.

The overall number of cases of cancer in the metal-on-metal cohort was no larger than the expected number of cancers in the Finnish population (378 observed $v 400$ expected cases, standardised incidence ratio 0.95 (95\% confidence 0.85 to 1.04 ) (table $2 \Downarrow$ ). The overall risk of cancer in the metal-on-metal cohort was also no higher than in the non-metal-on-metal cohort (relative risk $0.92,0.81$ to 1.05 ).

Table 3 shows the results of the analysis of standardised incidence ratios between the metal-on-metal cohort and the non-metal-on-metal cohort $\downarrow$.

The incidence of lung cancer, both in the metal-on-metal and in the non-metal-on-metal cohorts, was significantly lower than in the comparable Finnish population (table $2 \Downarrow$ ). The standardised incidence ratio of the metal-on-metal cohort for lung cancer was only 0.42 ( 0.18 to 0.81$)$ during the first two years after the operation (table $4 \Downarrow$ ).

There were five soft tissue sarcomas in the metal-on-metal cohort (standardised incidence ratio 2.18, 0.71 to 5.09) (table $2 \Downarrow$ ). The risk of soft tissue sarcoma in the metal-on-metal cohort was higher than in the non-metal-on-metal cohort, but not significantly so (relative risk $2.69,0.89$ to 6.71 ). As we chose to look at soft tissue carcinoma from many possible types of cancer this could be a chance finding. There was also one uterus sarcoma in the metal-on-metal cohort, which was included in the category of uterine cancer, not soft tissue sarcoma.

Supplementary table $\mathrm{C}$ in the appendix describes the cases of sarcoma in the metal-on-metal cohort.

The standardised incidence ratio of skin melanoma in the metal-on-metal cohort was 1.37 (0.82 to 2.13), but it was still lower than in the non-metal-on-metal cohort $(1.55,1.21$ to 1.95$)$ (table $2 \Downarrow$ ). The incidence of basal cell carcinoma in the metal-on-metal cohort was higher than the expected number of cancers from the Finnish population $(1.37,1.15$ to 1.61$)$ (table 2 ) and in the non-metal-on-metal cohort (relative risk 1.32, 1.06 to 1.66). As we chose to look at basal cell carcinomas from many possible types of cancer this could be a chance finding. 


\section{Discussion}

\section{Conclusions and policy implications}

This population based study shows that the overall short term risk of cancer is not increased in people with metal-on-metal hip implants. This finding is in accordance with previous findings with traditional total hip arthroplasty and first generation metal-on-metal-implants. ${ }^{17}{ }^{25} 26$ The incidence of basal cell carcinoma in the metal-on-metal cohort, however, was increased compared with the average population and with the non-metal-on-metal cohort . The risk of soft tissue sarcoma of the metal-on-metal cohort was also increased, but not significantly so, compared with the risk in the non-metal-on-metal cohort. These increased risks of basal cell carcinoma and soft tissue sarcoma might be chance findings. We know that there is a 20-40 year latency period between the initiation and outcome for some solid malignant tumours, while promotion effects might be observed after a lag of only some years. Metal-on-metal hip replacements should be used cautiously, especially in young patients, until more data are available. These data will be updated on a yearly basis.

\section{Strengths and limitations of study}

A strength of our study was the population based design with high numbers of patients with metal-on-metal implants. Weaknesses were the short follow-up time and the lack of information on potential confounding factors of risk of cancer such as smoking, which might affect the results.

\section{Comparison with other studies}

The metallurgical and tribological properties of modern metal-on-metal implants are, in theory, superior to those of the first generation metal-on-metal-implants. ${ }^{27}$ There has been no increase in the risk of cancer in patients who underwent first generation metal-on-metal total hip arthroplasty, even in long term follow-up. ${ }^{18}$ The mode of failure of the McKee-Farrar prostheses was partly similar to that of the modern hip implants. McKee-Farrar prostheses were revised because of aseptic loosening ${ }^{28}$ and granulomas and metallosis. For modern metal-on-metal implants, the wear of bearing surfaces is a common reason for early revisions. ${ }^{8-11}$ Metallic debris has been found in lymphatic and bone marrow tissue distant from the hip some years after total hip arthroplasty. ${ }^{29}{ }^{30}$ Serum concentrations of chromium and cobalt are higher after metal-on-metal total hip arthroplasty than after metal-on-polyethylene total hip arthroplasty. ${ }^{31}$ In early studies based on data including McKee-Farrar prostheses, there was an increased risk for lymphoma and leukaemia. ${ }^{32}$ This finding was not verified in the longer follow-up of the same cohorts. ${ }^{18}{ }^{34} 35 \mathrm{We}$ also found no increased risk of haematopoietic cancers in patients with metal-on-metal implants in the current study.

Individuals with rheumatoid arthritis and other autoimmune diseases are at increased risk of non-Hodgkin's lymphoma and leukaemia. ${ }^{22}$ Substantial consumption of antirheumatic drugs can also affect the risk of cancer. ${ }^{23}$ Removal of patients with rheumatoid arthritis from the metal-on-metal and the reference cohorts could have caused bias in our results when we compared these cohorts with the Finnish population, which includes rheumatoid patients. We think, however, that this bias would be minute.

A low incidence of lung cancer in patients with conventional total hip arthroplasty ${ }^{17} 252636$ and in patients with the first generation metal-on-metal total hip arthroplasty ${ }^{18}$ is a constant finding in epidemiological studies. The risk of osteoarthritis of the hip is lower in male smokers than in non-smokers. ${ }^{35}$ Current data support the earlier findings. Previous studies in patients undergoing metal-on-polyethylene total hip arthroplasty ${ }^{17} 2737$ and first generation metal-on-metal total hip arthroplasty ${ }^{18}$ showed no increased risk of gastrointestinal cancers. This is in accordance with our findings. In a Swedish cohort study based on data from conventional total hip implants, there was an increased risk of renal cancer. ${ }^{38}$ This finding has not been verified in later studies in patients with metal-on-polyethylene total hip ${ }^{17}{ }^{37}$ or first generation metal-on-metal ${ }^{18}$ implants. There was also no association between other cancers of the urinary tract and metal-on-metal total hip arthroplasty. ${ }^{18}$ The current data support these latest findings. According to our data, the incidence of prostate cancer was not increased either in the metal-on-metal cohort or in the metal-on-polyethylene, ceramic-on-polyethylene, and ceramic-on-ceramic cohort. This also agrees with findings of earlier studies. ${ }^{173638}$

Some ${ }^{26}{ }^{36-38}$ but not all ${ }^{17}$ earlier studies found an association between the risk of melanoma and conventional total hip arthroplasty. The incidence of melanoma in the non-metal-on-metal cohort in our study was higher than in the Finnish general population. The incidence of melanoma in the metal-on-metal cohort was also increased, but not significantly so. These findings might be caused by survey bias.

McKee-Farrar prostheses were not associated with any type of skin cancers. ${ }^{18}$ We found an increased risk of basal cell carcinoma in the metal-on-metal cohort. We are not aware that this has been reported before. As we looked at basal cell carcinomas, from many possible cancer types, this could be a chance finding. In previous studies on total hip arthroplasty patients, basal cell carcinoma has either not been registered at all or has been included in the category of other skin cancers. ${ }^{36}$ Our finding might reflect a diagnostic bias, and indeed we observed the highest standardised incidence ratio during the first two years after the operation. It has been stated, however, that there is an association between an increased concentration of metal ions because of hip resurfacing and reduced blood T cell count. ${ }^{39} \mathrm{CD} 4$ lymphocytopenia, on the other hand, is a risk factor for basal cell carcinoma, at least in patients with organ transplant who have compromised immune systems. ${ }^{40}$

The risk of soft tissue sarcoma in the metal-on-metal cohort was increased but not significantly so. As we looked at soft tissue sarcomas from many possible cancer types, this might be a chance finding. The total number of cases of sarcoma in the current study was small. None of the sarcomas in the metal-on-metal cohort were found in the hip joint near the implant. Only 52 cases of local sarcoma at the site of a hip prosthesis have been reported worldwide, including only five cases in patients with metal-on-metal-implants. ${ }^{41}{ }^{42}$ Previous studies of conventional total hip arthroplasty or first generation metal-on-metal total hip arthroplasty have not found an increased risk of sarcoma. ${ }^{17182736}$ The sarcoma cases in our metal-on-metal cohort are described in supplementary table $\mathrm{C}$ in the appendix. All sarcomas found in patients with a metal-on-metal hip implant in Finland were diagnosed during the last three years of the follow-up (2008-10). Of the six sarcomas, one was included in the standardised incidence ratio analysis in uterine cancers and the five others in soft tissue. The patient with the uterus sarcoma had a baby at the age of 33, one year after arthroplasty. Longer follow-up is needed to assess the sarcoma issue.

Contributors: All authors were involved in the study design, analysis and interpretation of the data, and drafting and final approval of the manuscript. EP is guarantor. 


\section{What is already known on this topic}

Metal debris from hip implants can be associated with chromosomal aberrations and DNA damage

No increased risk of cancer has been found after conventional metal-on-polyethylene total hip arthroplasty

\section{What this study adds}

The overall risk of cancer in patients with metal-on-metal hip implants is not increased

There is a suggestion of an increased risk of basal cell carcinoma and sarcoma at the early stage of follow-up, though this could be a chance finding

Funding: This study was funded by Turku University Hospital (KTM) and Sigrid Juselius Foundation and Helsinki University Central Hospital (VR).

Competing interests: All authors have completed the ICMJE uniform disclosure form at www.icmje.org/coi_disclosure.pdf (available on request from the corresponding author) and declare: during the previous three years, TV has received payment from DePuy for consultation of the cancer risk of the McKee-Farrar prosthesis; $A E$ has received payment for lectures from DePuy, Stryker, Biomet and for travel/accommodations/meeting expenses from DePuy, Zimmer, Biomet, Smith and Nephew; VR has received payment for lectures from Stryker, Smith and Nephew, DePuy, Zimmer, Bayer, Sanofi, and Biomet; PV has received consulting fee or honorarium from Biomet and Smith and Nephew, and support for travel to meetings from Biomet, Smith and Nephew, and Zimmer, and payment for consultancy from Biomet, and payment for lectures from Biomet, Smith and Nephew, DePuy, and Stryker.

Ethical approval: This study was approved by the National Institute for Health and Welfare and by the Finnish Data Protection Ombudsman. Data sharing: No additional data available.

1 Gross TP, Liu F, Webb LA. Clinical Outcome of the metal-on-metal hybrid Corin Corme 2000 hip resurfacing system: an up to 11 -year follow-up study. $J$ Arthroplasty 2011;27:533-8

2 Treacy RB, McBryde CW, Shears E, Pynsent $\mathrm{PB}$. Birmingham hip resurfacing: a minimum follow-up of ten years. J Bone Joint Surg Br 2011;93:27-33.

3 Meding JB, Meding LK, Keating EM, Berend ME. Low incidence of groin pain and early failure with large metal articulation total hip arthroplasty. Clin Orthop Relat Res 2012;470:388-94.

4 Garbuz DS, Tanzer M, Greidanus NV, Masri BA, Duncan CP. Metal-on-metal hip resurfacing versus large-diameter head metal-on-metal total hip arthroplasty: a randomized clinical trial. Clin Orthop Relat Res 2010;468:318-25.

5 Australian Orthopaedic Association. National Joint Replacement Registry. Annual Report 2010.

6 National Joint Registry for England and Wales (NJR England-Wales). 8th Annual Report 2011.

7 Cohen D. How safe are metal-on-metal hip implants? BMJ 2012;344:e1410

8 Pandit H, Glyn-Jones S, McLardy-Smith P, Gundle R, Whitwell D, Gibbons CL, et al. Pseudotumours associated with metal-on-metal hip resurfacings. J Bone Joint Surg Br 2008:90:847-51.

9 Grammatopolous G, Pandit H, Kwon YM, Gundle R, McLardy-Smith P, Beard DJ, et al. Hip resurfacings revised for inflammatory pseudotumour have a poor outcome. J Bone Joint Surg Br 2009;91:1019-24.

10 Ollivere B, Darrah C, Barker T, Nolan J, Porteous MJ. Early clinical failure of the Birmingham metal-on-metal hip resurfacing is associated with metallosis and soft-tissue necrosis. J Bone Joint Surg Br 2009;91:1025-30.

11 Shimmin AJ, Bare J, Back DL. Complications associated with hip resurfacing arthroplasty. Orthop Clin North Am 2005;36:187-93, ix

12 Shea KD, Lundeen GA, Bloebaum RD, Bachus KN, Zou L. Lymphoreticular dissemination of metal particles after primary joint replacements. Clin Orthop Relat Res 1997:338:219-226

13 Urban RM, Jacobs JJ, Tomlinson MJ, Gavrilovic J, Black J, Peoc'h M. Dissemination of wear particles to the liver, spleen, and abdominal lymph nodes pf patients with hip or knee replacement. J Bone Joint Surg Am 2000;82:457-476.

14 Case CP, Langkamer VG, Howell RT, Webb J, Standen G, Palmer M, et al. Preliminary observations on possible premalignant changes in bone marrow adjacent to worn total hip arthroplasty implants. Clin Orthop Relat Res 1996;329(suppl):269-79.

15 Bonassi S, Hagmar L, Strömberg U, Montagud AH, Tinnerberg H, Forni A, et al. Chromosomal aberrations in lymphocytes predict human cancer independently of exposure to carcinogens. European Study Group on Cytogenetic Biomarkers and Health. Cancer Res 2000;60:1619-25.

16 Daley B, Doherty AT, Fairman B, Case CP. Wear debris from hip or knee replacements causes chromosomal damage in human cells in tissue culture. J Bone Joint Surg Br 2004;86:598-606.
17 Visuri T, Pulkkinen P, Paavolainen P, Pukkala E. Cancer risk is not increased after conventional hip arthroplasty. a natiowide study from the Finnish Arthroplasty Register with follow-up of 24,636 patients for a mean of 13 years. Acta Orthopaedica 2010;81:77-81.

18 Visuri T, Pukkala E, Paavolainen P, Pulkkinen P, Riska EB. Cancer risk after metal on metal and polyethylene on metal total hip arthroplasty. Clin Orthop Relat Res 1996;329 suppl:S280-9.

19 Cohen D. Out of joint: the story of the ASR. BMJ 2011:13:342.

20 Garbuz DS, Tanzer M, Greidanus NV, Masri BA, Duncan CP. The John Charnley Award: Metal-on-metal hip resurfacing versus large-diameter head metal-on-metal total hip arthroplasty: a randomized clinical trial. Clin Orthop Relat Res 2010;468:318-25.

21 Seppänen M, Mäkelä K, Virolainen P, Remes V, Pulkkinen P, Eskelinen A. Hip resurfacing arthroplasty: short term survivorship of 4,401 hips from the Finnish Arthroplasty Register. Acta Orthop 2012;83:207-13

22 Santana V, Rose NR. Neoplastic lymphoproliferation in autoimmune disease: an updated review. Clin Immunol Immunopathol 1992;63:205-13.

23 Kauppi MJ, Savolainen HA, Anttila VJ, Isomäki HA. Increased risk of leukaemia in patients with juvenile chronic arthritis treated with chlorambucil. Acta Paediatr 1996;85:248-50.

24 Paavolainen P. Hamalainen M, Mustonen H, Slatis P. Registration of arthroplasties in Finland. A nationwide prospective project. Acta Orthop Scand Supp/ 1991;241:27-30.

25 Goldacre MJ, Wotton CJ, Seagroatt V, Yates D. Cancer following hip and knee arthroplasty: record linkage study. Br J Cancer 2005;92:1298-301.

26 Onega T, Baron J, MacKenzie T. Cancer after total joint arthroplasty: a meta-analysis. Cancer Epidemiol Biomarkers Prev 2006;15:1532-7.

27 Paavolainen P, Pukkala E, Pulkkinen P, Visuri T. Cancer incidence in Finnish hip replacement patients from 1980 to 1995 . A nationwide cohort study involving 31,651 patients. J Arthroplasty 1999;14:272-80.

28 Zahiri CA, Schmalzried TP, Ebramzadeh E, Szuszczewicz ES, Salib D, Kim C, et al. Lessons learned from loosening of the McKee-Farrar metal-on-metal total hip replacement. $J$ Arthroplasty 1999;14:326-32.

29 Langkamer VG, Case CP, Heap P, Taylor A, Collins C, Pearse M, et al. Systemic distribution of wear debris after hip replacement: a cause of concern? J Bone Joint Surg Br 1992; 74:831.

30 Case CP, Langkamer VG, James C, Palmer MR, Kemp AJ, Heap PF, et al. Widespread dissemination of metal debris from implants. J Bone Joint Surg 1994;76:701.

31 MacDonald SJ, McCalden RW, Chess DG, Bourne RB, Rorabeck CH, Cleland D, et al. Metal-on-metal versus polyethylene in hip arthroplasty: a randomized clinical trial. Clin Orthop 2003;406:282-96.

32 Gillespie WJ, Frampton CMA, Henderson RJ, Ryan PM. The incidence of cancer following total hip replacement. J Bone Joint Surg 1988;70:539-42.

33 Visuri T, Koskenvuo M. Cancer risk after McFarrar total hip replacement. Orthopaedics 1991;14:1-6.

34 Gillispie WJ, Henry DA, O'Connell DL, Kendrick S, Juszczak E, McInneny K, et al. Development of hematopoietic cancers after implantation of total joint replacement. Clin Orthop 1996;329s:290-6.

35 Järvholm B, Lewold S, Malchau H, Vingaard E. Age, bodyweight, smoking habits and the risk of severe osteoarthritis in the hip and knee in men. Eur J Epidemiol 2005;20:537-42.

36 Visuri T, Pukkala E, Pulkkinen P, Paavolainen P. Decreased cancer risk in patients who have been operated on with total hip and knee arthroplasty for primary osteoarthosis. Acta Orthop Scand 2003:74:351-60.

37 Olsen JO, McLaughlin JK, Nyren O, Mellamkjaer L, Lipworth L, Blot WJ, et al. Hip and knee implantations among patients with osteoarthritis and risk of cancer: a record-linkage study from Denmark. Int J Cancer 1999;81:719-22.

38 Nyren O, McLaughlin JK, Gridley G, Ekbom A, Johnell OJ, Fraumeni JF, et al. Cancer risk after hip replacement with metal implants: a population-based cohort study in Sweden. J Natl Cancer Inst 1995:87:28-33.

39 Hart AJ, Skinner JA, Winship P, Faria N, Kulinskaya E, Webster D, et al. Circulating levels of cobalt and chromium from metal-on-metal hip replacement are associated with CD8+ T-cell lymphopenia. J Bone Joint Surg Br 2009;91:835-42.

40 Kwasniak LA, Garcia-Zuazaga J. Basal cell carcinoma: evidence-based medicine and review of treatment modalities. Int J Dermatol 2011;50:645-58.

41 Visuri T, Pulkkinen P, Paavolainen P. Malignant tumors at the site of total hip prosthesis. Analytic review of 46 cases. J Arthroplasty 2006;21:311-23

42 Min WK, Kim SY, On CW, Kim SJ, Park TI, Koo KH. Malignant fibrous histiocytoma arising in the area of total hip replacement. J Bone Spine 2008;75:319-21.

\section{Accepted: 15 June 2012}

\section{Cite this as: BMJ 2012;345:e4646}

This is an open-access article distributed under the terms of the Creative Commons Attribution Non-commercial License, which permits use, distribution, and reproduction in any medium, provided the original work is properly cited, the use is non commercial and is otherwise in compliance with the license. See: http://creativecommons.org/licenses/by$\mathrm{nc} / 2.0 /$ and http://creativecommons.org/licenses/by-nc/2.0/legalcode. 


\section{Tables}

Table 1/ Number of patients with hip arthroplasty according to type of implant and age at operation and number of person years

\begin{tabular}{|c|c|c|c|c|c|c|c|c|}
\hline \multirow[b]{3}{*}{ Age (years) } & \multicolumn{4}{|c|}{ Metal-on-metal cohort } & \multicolumn{4}{|c|}{ Non-metal-on-metal cohort ${ }^{\star}$} \\
\hline & \multicolumn{2}{|c|}{ Men } & \multicolumn{2}{|c|}{ Women } & \multicolumn{2}{|c|}{ Men } & \multicolumn{2}{|c|}{ Women } \\
\hline & No of people & Person years & No of people & Person years & No of people & Person years & No of people & Person years \\
\hline $0-9$ & 1 & 1 & - & - & - & - & - & - \\
\hline $10-19$ & 5 & 12 & 3 & 15 & - & - & - & - \\
\hline $20-29$ & 25 & 86 & 16 & 49 & 4 & 15 & 7 & 20 \\
\hline $30-39$ & 158 & 385 & 67 & 210 & 30 & 95 & 20 & 74 \\
\hline $40-49$ & 741 & 2399 & 468 & 1326 & 143 & 562 & 157 & 449 \\
\hline 50-59 & 2275 & 7144 & 1642 & 5236 & 850 & 3076 & 922 & 3383 \\
\hline $60-69$ & 2257 & 9293 & 1581 & 6431 & 2261 & 9983 & 2739 & 11076 \\
\hline 70-79 & 762 & 3240 & 594 & 2287 & 3044 & 16530 & 5394 & 25719 \\
\hline$\geq 80$ & 65 & 254 & 48 & 208 & 697 & 6153 & 1954 & 16071 \\
\hline Total & 6289 & 22813 & 4419 & 15764 & 7029 & 36413 & 11193 & 56792 \\
\hline
\end{tabular}

*Metal-on-polyethylene, ceramic-on-polyethylene, and ceramic-on-ceramic bearing surfaces. 
Table 2| Observed and expected numbers of cases of cancer in Finnish population and standardised incidence ratios (SIR) with 95\% confidence intervals in patients with hip arthroplasty according to type of implant and site of cancer

\begin{tabular}{|c|c|c|c|c|c|c|}
\hline \multirow[b]{2}{*}{ Primary site } & \multicolumn{3}{|c|}{ Metal-on-metal cohort } & \multicolumn{3}{|c|}{ Non-metal-on-metal cohort ${ }^{\star}$} \\
\hline & Observed & Expected & $\operatorname{SIR}(95 \% \mathrm{CI})$ & Observed & Expected & SIR (95\% CI) \\
\hline All sites & 378 & 400 & 0.95 (0.85 to 1.04$)$ & 1672 & 1601 & $1.04(0.99$ to 1.09$)$ \\
\hline Stomach & 12 & 10 & 1.26 (0.65 to 2.20$)$ & 46 & 4645.8 & $1.00(0.73$ to 1.33$)$ \\
\hline Colon & 17 & 22 & $0.79(0.46$ to 1.25$)$ & 97 & 111 & $0.88(0.71$ to 1.07$)$ \\
\hline Lung & 23 & 40 & $0.58\left(0.37\right.$ to $\left.0.86^{\star \star}\right)$ & 104 & 154 & $0.68\left(0.55\right.$ to $\left.0.81^{\star \star \star}\right)$ \\
\hline Uterus & 10 & 10 & $1.01(0.48$ to 1.85$)$ & 49 & 49 & $1.00(0.74$ to 1.32$)$ \\
\hline Prostate & 109 & 92 & $1.18(0.97$ to 1.41$)$ & 292 & 283 & $1.03(0.92$ to 1.15$)$ \\
\hline Kidney & 11 & 13 & 0.85 (0.43 to 1.52$)$ & 52 & 51 & $1.02(0.76$ to 1.33$)$ \\
\hline Bladder & 9 & 13 & $0.68(0.31$ to 1.28$)$ & 70 & 60 & $1.17(0.91$ to 1.47$)$ \\
\hline Soft tissue sarcoma & 5 & 2 & $2.18(0.71$ to 5.09$)$ & 9 & 9 & $0.97(0.44$ to 1.83$)$ \\
\hline Non-Hodgkin's lymphoma & 14 & 16 & 0.89 (0.49 to 1.49$)$ & 76 & 63 & 1.21 (0.96 to 1.51$)$ \\
\hline Hodgkin's lymphoma & 1 & 1 & $1.05(0.03$ to 5.85$)$ & 1 & 3 & 0.41 (0.01 to 2.25 \\
\hline Multiple myeloma & 4 & 5 & $0.88(0.24$ to 2.25$)$ & 25 & 23 & $1.11(0.72$ to 1.63$)$ \\
\hline Leukaemia & 5 & 7 & $0.69(0.22$ to 1.61$)$ & 31 & 32 & $0.96(0.65$ to 1.36$)$ \\
\hline Melanoma & 19 & 14 & $1.37(0.82$ to 2.13$)$ & 70 & 45 & $1.55\left(1.21\right.$ to $\left.1.95^{\star \star \star}\right)$ \\
\hline Basal cell carcinoma & 130 & 95 & $1.37\left(1.15\right.$ to $\left.1.61^{\star \star \star}\right)$ & 504 & 475 & $1.06(0.97$ to 1.15$)$ \\
\hline
\end{tabular}

${ }^{*}$ Metal-on-polyethylene, ceramic-on-polyethylene, and ceramic-on-ceramic bearing surfaces.

${ }^{* *} \mathrm{P}<0.01$.

$* * * P<0.001$. 
Table 3| Ratios of standardised incidence ratios (95\% confidence intervals) in patients with hip arthroplasty with metal-on-metal or non-metal-on-metal ${ }^{*}$ implants by site of cancer

\begin{tabular}{ll} 
All sites & Ratio (95\% Cl) \\
\hline Stomach & $0.91(0.81$ to 1.01$)$ \\
\hline Colon & $1.26(0.67$ to 2.35$)$ \\
\hline Lung & $0.90(0.54$ to 1.49$)$ \\
\hline Prostate & $0.86(0.55$ to 1.34$)$ \\
\hline Kidney & $1.14(0.92$ to 1.42$)$ \\
\hline Bladder & $0.84(0.44$ to 1.59$)$ \\
\hline Uterus & $0.58(0.29$ to 1.15$)$ \\
\hline Soft tissue & $1.01(0.52$ to 1.97$)$ \\
\hline Non-Hodgkin's lymphoma & $2.25(0.79$ to 6.42$)$ \\
\hline Hodgkin's lymphoma & $0.73(0.42$ to 1.29$)$ \\
\hline Multiple myeloma & $2.60(0.27$ to 24.90$)$ \\
\hline Leukaemia & $0.79(0.29$ to 2.18$)$ \\
\hline Melanoma & $0.72(0.29$ to 1.79$)$ \\
\hline Basal cell carcinoma & $0.88(0.53$ to 1.46$)$ \\
\hline
\end{tabular}

*Metal-on-polyethylene, ceramic-on-polyethylene, and ceramic-on-ceramic bearing surfaces. 
Table 4 | Observed and expected numbers of cases of cancer in Finnish population and standardised incidence ratios (SIR) with $95 \%$ confidence intervals by time since hip arthroplasty

$<2$ years after operation

Observed Expected SIR $(95 \% \mathrm{Cl})$

\begin{tabular}{lcccccc} 
All sites & 183 & 195 & $0.94(0.81$ to 1.07$)$ & 194 & 205 & $0.95(0.83$ to 1.09$)$ \\
\hline Stomach & 4 & 5 & $0.86(0.23$ to 2.20$)$ & 8 & 5 & $1.65(0.71$ to 3.26$)$ \\
\hline Colon & 7 & 11 & $0.67(0.27$ to 1.37$)$ & 10 & 11 & $0.90(0.43$ to 1.65$)$ \\
\hline Lung & 8 & 19 & $0.42\left(0.18\right.$ to $\left.0.81^{* *}\right)$ & 15 & 21 & $0.73(0.41$ to 1.20$)$ \\
\hline Uterus & 3 & 5 & $0.60(0.12$ to 1.76$)$ & 7 & 5 & $1.42(0.57$ to 2.92$)$ \\
\hline Prostate & 56 & 44 & $1.26(0.95$ to 1.64$)$ & 53 & 48 & $1.10(0.83$ to 1.44$)$ \\
\hline Kidney & 4 & 6 & $0.64(0.17$ to 1.62$)$ & 7 & 7 & $1.06(0.43$ to 2.18$)$ \\
\hline Bladder & 7 & 6 & $1.09(0.44$ to 2.24$)$ & 2 & 7 & $0.29(0.04$ to 1.05$)$ \\
\hline Soft tissue & 2 & 1 & $1.78(0.22$ to 6.44$)$ & 3 & 1 & $2.56(0.53$ to 7.49$)$ \\
\hline Non-Hodgkin's lymphoma & 4 & 8 & $0.52(0.14$ to 1.33$)$ & 10 & 8 & $1.24(0.59$ to 2.28$)$ \\
\hline Hodgkin's lymphoma & 0 & 1 & $0.00(0.00$ to 7.83$)$ & 1 & 1 & $2.08(0.05$ to 11.59$)$ \\
\hline Multiple myeloma & 2 & 2 & $0.90(0.11$ to 3.26$)$ & 2 & 2 & $0.86(0.10$ to 3.09$)$ \\
\hline Leukaemia & 2 & 4 & $0.57(0.07$ to 2.05$)$ & 3 & 4 & $0.81(0.17$ to 2.36$)$ \\
\hline Melanoma & 9 & 7 & $1.33(0.61$ to 2.52$)$ & 10 & 7 & $1.40(0.67$ to 2.57$)$ \\
\hline Basal cell carcinoma & 68 & 46 & $1.48\left(1.15\right.$ to $\left.1.87^{* *}\right)$ & 62 & 49 & $1.27(0.98$ to 1.63$)$ \\
\hline
\end{tabular}

${ }^{* *} \mathrm{P}<0.01$.

$\geq 2$ years after operation

\section{Observed Expected SIR $(95 \% \mathrm{Cl})$}

